\title{
Pelatihan Implementasi Manajemen Dalam Menambah Iman dan Taqwa Masyarakat Desa Gunung Picung Bogor
}

\author{
${ }^{1}$ Ade Onny Siagian, ${ }^{2}$ Hadion Wijoyo, ${ }^{3}$ Suherman \\ ${ }^{1}$ Fakultas Manajemen dan Bisnis, Universitas Bina Sarana Informatika, Jakarta \\ ${ }^{2}$ STMIK Dharmapala Riau \\ ${ }^{3}$ STIAB Smaratungga
}

\begin{abstract}
Alamat Surat
Email: ade.aoy@bsi.ac.id, hadion.wijoyo@lecturer.stmikdharmapalariau.ac.id** herusuherman@smaratungga.ac.id
\end{abstract}

Article History:

Diajukan: 20 Januari 2021; Direvisi: 2 Februari 2021; Accepted: 5 Februari 2021

\begin{abstract}
ABSTRAK
Tulisan ini bertujuan untuk meningkatkan motivasi wirausaha dikalangan warga Gunung Picung, meningkatkan kemampuan bersaing dalam wirausaha untuk meningkatkan kesejahteraan, membudayakan semangat, sikap, perilaku dan kemampuan kewirausahaan dan keuangan serta mengembangkan dan meningkatkan pengetahuan keagamaan, ahlak yang baik, manajemen keuangan dan pemasaran dan orientasi kewirausahaan terhadap warga Gunung Picung Teknik pendekatan dilakukan dengan metode pelatihan dan tanya jawab secara langsung, Hasil kegiatan dapat meningkatkan kemampuan peserta untuk untuk meningkatkan motivasi wirausaha yang akan meningkatkan perekonomian keluarga di masa yang akan datang.
\end{abstract}

Kata kunci: Implementasi Manajemen, Motivasi, Wirausaha

\section{ABSTRACT}

This paper aims to increase entrepreneurial motivation among the residents of Mount Picung, increase the ability to compete in entrepreneurship to improve welfare, cultivate entrepreneurial spirit, attitudes, behavior and abilities and finance as well as develop and increase religious knowledge, good morals, financial management and marketing and entrepreneurial orientation. towards the residents of Mount Picung Teknik the approach is carried out by training methods and direct question and answer. The results of the activity can increase the ability of participants to increase entrepreneurial motivation which will improve the family economy in the future.

Keywords: Management Implementation, Motivation, Entrepreneurship

\section{PENDAHULUAN}

Pengabdian Melihat potensi yang ada di daerah Jawa Barat khususnya Kampung Gunung Picung, Desa Gunung Picung, Kecamatan Pamijahan, Kota Bogor. dimana disana memiliki potensi wisata alam yang indah antara lain ada air terjun Curug Balong Indah dan wisata pemandangan cantik underwater yang sangat menawan, aneka buah - buahan serta wisata kuliner terkenal sekitar Pamengpeuk yang lezat tetapi belum banyak inovasi dari warga yang masih berfikir dan bekerja secara tradisional. Hal tersebut menarik perhatian kami sebagai dosen Fakultas Ekonomi Manajemen Universitas Bina Sarana Informatika untuk turut menyumbangkan sedikit ilmu yang kami miliki guna membantu masyarakat dalam meningkatkan potensi daerahnya melalui Implementasi ilmu manajemen dalam meningkatkan iman dan taqwa masyarakat desa Gunung Picung, agar mereka 
dapat bersaing dengan darah - daerah lain di Jawa Barat maupun daerah lainnya di Indonesia (Soedarwo et al., 2017).

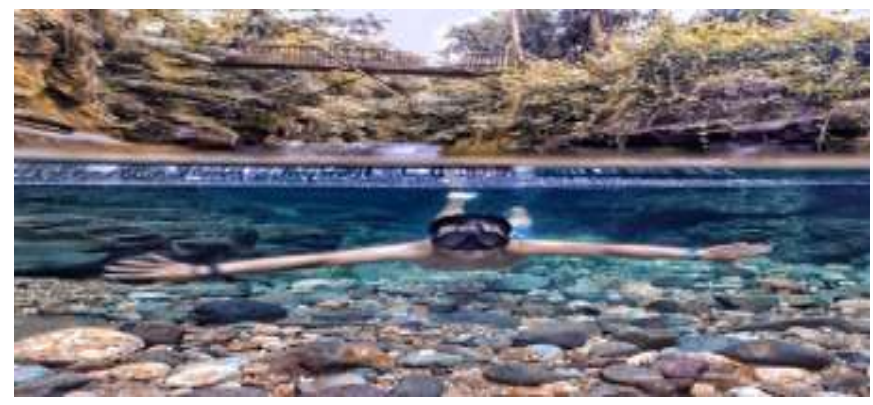

Gambar 1

(Pemandangan Underwater Cantik yang menawan Curug Balong Indah)

Masyarakat desa Gunung Picung, Pamijahan, Bogor, sebagian besar bermata pencaharian sebagai petani, pedagang dan sebagai pemandu wisata. Oleh karena itu, dirasakan perlu diadakan kegiatan yang dapat memberikan manfaat tambahan ilmu, pemahaman keagamaan dan keterampilan kewirausahaan kepada Masyarakat umumnya dan khususnya generasi muda, dalam bentuk Pelatihan kewirausahaan dan Diskusi Ilmu Manajemen dan Ceramah keagamaan dalam meningkatkan Iman dan Taqwa masyarakat Gunung Picung, Pamijahan, Bogor, agar seluruh elemen masyarakat siap bersaing dalam menghadapi persaingan pasar yang sangat ketat dan global (Onny Siagian, 2020). Diharapkan warga Gunung Picung, tidak hanya terampil berwirausaha tetapi juga memiliki keimanan dan ketaqwaan, mulai dari generasi muda hingga orang dewasa, sehingga dapat memajukan daerahnya. Pengabdian Kepada Masyarakat (PKM) yang dilakukan oleh beberapa dosen dari Fakultas Ekonomi program studi Manajemen, Universitas Bina Sarana Informatika (Ade Onny Siagian, 2020). Kegiatan ini merupakan bentuk keterlibatan perguruan tinggi dalam proses meningkatkan kualitas generasi muda Indonesia pada umumnya dan Masyarakat Gunung Picung, Pamijahan, Bogor, pada khususnya, yang diharapkan akan bermanfaat bagi kedua belah pihak (Sonya \& Wulan, 2018). Kegiatan Pengabdian Kepada Masyarakat Gunung Picung, ini diharapkan bukan hanya sekedar kegiatan tetapi kedepan akan terus ada kegiatan-kegiatan di bidang Manajemen lainnya yang membutuhkan tambahan ilmu pengetahuan dan wawasan sehingga kegiatan Pengabdian Kepada Masyarakat (PKM) ini terus berkelanjutan. Pelatihan Manajemen Kewirausahaan, Pemasaran, Keuangan (O. Siagian, 2020), dan Keagamaan dalam meningkatkan iman dan taqwa masyarakat Indonesia umumnya dan masyarakat desa Gunung Picung khususnya. Sasaran kegiatan Pengabdian kepada masyarakat (PKM) ini adalah dengan mengajak warga untuk mengikuti penyuluhan dan pelatihan "Pelatihan Implementasi Manajemen Dalam menambah Iman Dan Taqwa Masyarakat Desa Gunung Picung Bogor"

\section{RUMUSAN MASALAH}

Masyarakat desa Gunung Picung, Pamijahan, Bogor, sebagian besar bermata pecaharian sebagai petani, pedagang dan sebagai pemandu wisata. Dirasakan perlu diberkan pembekalan tambahan ilmu manajemen, pemahaman keagamaan dan keterampilan kewirausahaan.

Dalam kondisi persaingan pasar dan kemajuan teknologi yang sangat pesat dirasakan sangat perlu memberikan pelatihan - pelatihan kewirausahaan, pemasaran, keuangan dan ilmu keagamaan guna mencetak generasi muda dan masyarakat wirausaha yang siap bersaing memiliki moral, ahlak, keagamaan dan pengetahuan yang baik. Sehingga meningkatkan kualitas pribadi masyarakat dan generasi muda dalam menghadapi tantangan persaingan ketat dan global secara umum (Siagian et al., 2020).

\section{TUJUAN DAN MANFAAT}

Tujuan dari pelatihan ini, antara lain: 
a. Meningkatkan motivasi wirausaha dikalangan warga Gunung Picung

b. Meningkatkan kemampuan bersaing dalam wirausaha untuk meningkatkan kesejahteraan

c. Membudayakan semangat, sikap, perilaku dan kemampuan kewirasuahaan dan keuangan

d. Mengembangkan dan meningkatkan pengetahuan keagamaan, ahlak yang baik, manajemen keuangan dan pemasaran dan orientasi kewirausahaan terhadap warga Gunung Picung

\section{KEGIATAN}

Sasaran dari program Pengabdian Masyarakat ini adalah warga masyarakat Desa Gunung Picung, Kec. Pamijahan, Kota Bogor - Jawa Barat. Jumlah peserta pelatihan kurang lebih 30 orang.

Adapun pelaksanan dari kegiatan adalah sebagai berikut:
Hari
: Jumat s/d Minggu
Tanggal/Bulan
Waktu
: 09 - 11 Oktober 2020
Tempat
: Pukul 09.00 - 12.00 WIB
: Desa Gunung Picung, Kecamatan Pamijahan, Kota. Bogor, Jawa Barat

\section{APLIKASI}

\section{A. Manajemen Iman dan Taqwa}

Kata iman dan Taqawa sangat populer dalam ajaran islam, kata ini selalu disebut-sebut di dalam ceramah-ceramah, pidato baik di secara langsung, televisi ataupun radio. dan bahkan wasiat taqwa merupakan rukun dari khutbah jum'atan. disini dapat disimpulkan bahwa taqwa dan iman itu merupakan perioritas penting dalam ajaran islam. Kita sebagai umat islam haruslah mengerti apa yang dimaksud dengan iman dan taqwa yang biasa disingkat menjadi (IMTAQ) dalam kurikulum Sekolah Dasar, didalam Al-Quran sangat banyak disebutkan kata iman dan taqwa, ("Hai orang yang beriman, hai orang yang bertaqwa"). Menurut pendapat majelis' ulama sepakat bahwa Taqwa adalah sebuah kekuatan yang teguh dalam menjalankan/mengerjakan peirntah Allah dan menjauhi larangan-Nya. taqwa juga dikaitkan dengan sebuah prestasi yang bisa disebut dengan derajat atau tingkatan terhormat. Orang yang bertaqwa adalah orang yang dekat dengan Allah dan Allah yang akana mnjaganya dan memudahkan Rezeki baginya dan lainlain, dalam tanda kutip orang yang bertaqwa itu mendapat tempat yang dimuliakan oleh Allah SWT.(Saepudin et al., 2007) Iman adalah sebuah perasaan keyakinan, dalam bahasa arab istilah iman itu dibahasakan dengan I'tiqad yaitu keyakinan penuh. nah dalam konteks ini iman bisa dikatakan sebagai perasaan yakin. Dalam Sebuah sirah tauhid (Pendapat Ahli Shufi) bahwa dikatakan iman itu memiliki karakteristik:

$$
\text { ينقص و يزيد الإليمان }
$$

Bahasa diatas bisa kita artikan dengan: Keimanan itu bertambah dan berkurang Inilah yang dimaksud dengan karakteristik iman, hal ini juga bisa kita

bandingkan dengan jelas, dalam menjalankan sebuah ibadah seperti sholat misalnya, ibadah yang kita kerjakan setiap hari, terkadang kita semangat dan cepat berangkat pergi ke mesjid untuk sholat berjama'a namun kadang-kadang kita malas untuk melaksanakan sholat, itulah keimanan. Keimanan dapat berubah-berubah sewaktu-waktu.

Jika dilihat dari polanya, Iman dan Taqwa ini memiliki hubungan yang erat dan memilki ketergantungan keduanya. singkatnya, jika ketaqwaan itu merupakan ebuah derajat karena upaya kita dalam meningkatkan amal ibadah serta meninggalkan larangan Allah Swt untuk mencapai itu semua harus dimulai dengan keimanan, dalam membangun keimanan inilah yang harus diperhatikan, dalam keimanan ada beberapa unsur:

1. Yakin

2. Teguh 
3. Ikhlas

4. Tawakkal (Mujib, 2017)

Keempat ini merupakan tameng penting dalam membangun iman. Contohnya seperti ini, kita sudah yakin dengan kekuasaan Allah, maka kita harus teguh dalam berusaha dan selalu memohon kepadanya, ihlas dari apa yang hadapi dalam hidup dan apa yang kita amalkan dan berserah diri (tawakkal) dalam setiap kondisi. disini motif keraguan harus dibuang jauh-jauh, jangan pernah ragu bahwa Allah itu Maha Pengasih dan Penyayang setelah kita mengucapkan Bismillahirrahmanirrahim.

Dengan demikian Prinsip taqwa akan tumbuh dengan sendirinya. Menjalankan perintah Allah tidak terasa berat dan sangat nyaman. dan bahkan kita mampu berdakwah untuk menyeru saudara-saudara kita untuk mengingat Allah.mampu besedekah tanpa ada maksud selain karena Allah. mampu Naik Haji tanpa mengharap pujian dari orang lain., semua karena Allah. itulah hakikat Taqwa. Intinya adalah iman dan taqwa itu saling berkaitan dan berhubungan.

\section{B. Implementasi Iman dan Taqwa}

Masalah sosial budaya merupakan masalah alam pikiran dan realitas hidup masyarakat. Alam pikiran bangsa Indonesia adalah majemuk, sehingga pergaulan hidupnya selalu dipenuhi konflik dengan sesama orang Islam maupun dengan non- Islam. Pada zaman modern ini, dimungkinkan sebagian masyarakat antara yang satu dengan yang lainnya saling bermusuhan, yaitu ada ancaman kehancuran. Adaptasi modernisme, kendatipun tidak secara total yang dilakukan bangsa Indonesia selama ini, telah menempatkan bangsa Indonesia menjadikan bangsa Indonesia menjadi pengkhayal. Oleh karena itu, kehidupannya selalu terombang- ambing. Secara ekonomi bangsa Indonesia semakin tambah terpuruk. Hal ini karena di adaptasinya sistem kapitalisme dan melahirkan korupsi besar-besaran. Sedangkan di bidang politik, selalu muncul konflik di antara partai dan semakin jauhnya anggota parlemen dengan nilai-nilai qur'ani, karena pragmatis dan oportunis.

Di bidang sosial banyak munculnya masalah. Berbagai tindakan kriminal sering terjadi dan pelanggaran terhadap norma-norma bisa dilakukan oleh anggota masyarakat. Lebih memprihatinkan lagi adalah penyalahgunaan NARKOBA oleh anak-anak sekolah, mahasiswa, serta masyarakat. Persoalan itu muncul, karena wawasan ilmunya salah, sedang ilmu merupakan roh yang menggerakan dan mewarnai budaya. Hal itu menjadi tantangan yang amat berat dan menimbulkan tekanan. Sebagian besar permasalahan sekarang adalah bahwa umat islam berada dalam kehidupan modern yang serba mudah, serba bisa bahkan cenderung serba boleh. Setiap detik dalam kehidupan umat islam selalu berhadapan dengan hal-hal yang dilarang agamanya akan tetapi sangat menarik naluri kemanusiaanya, ditambah lagi kondisi religius yang kurang mendukung. Keadaan seperti ini sangat berbeda dengan kondisi umat islam terdahulu yang kental dalam kehidupan beragama dan situasi zaman pada waktu itu yang cukup mendukung kualitas iman seseorang. Olah karenanya dirasa perlu mewujudkan satu konsep khusus mengenai pelatihan individu muslim menuju sikap taqwa sebagai tongkat penuntun yang dapat digunakan (dipahami) muslim siapapun. Karena realitas membuktikan bahwa sosialisasi taqwa sekarang, baik yang berbentuk syariat seperti puasa dan lain-lain atau bentuk normatif seperti himbauan khatib dan lain-lain terlihat kurang mengena, ini dikarenakan beberapa faktor, diantaranya:

Muslim yang bersangkutan belum paham betul makna dari taqwa itu sendiri, sehingga membuatnya enggan untuk memulai,

1. Ketidaktahuannya tentang bagaimana, darimana dan kapan dia harus mulai merilis sikap taqwa,

2. Kondisi sosial dimana dia hidup tidak mendukung dirinya dalam membangun sikap taqwa.

Oleh karenanya setiap individu muslim harus paham pos - pos alternatif yang harus dilaluinya, diantaranya yang paling awal dan utama adalah gadhul bashar (memalingkan pandangan), karena pandangan (dalam arti mata dan telinga) adalah awal dari segala tindakan, 
penglihatan atau pendengaran yang ditangkap oleh panca indera kemudian diteruskan ke otak lalu direfleksikan oleh anggota tubuh dan akhirnya berimbas ke hati sebagai tempat bersemayam taqwa. Untuk membebaskan bangsa Indonesia dari persoalan tersebut, perlu diadakan revolusi pandangan. Dalam kaitan ini, iman dan takwa berperan menyelesaikan problema dan tantangan kehidupan modern tersebut. Hubungan religiusitas dan modernisasi (industrialisasi) merupakan persoalan rumit yang banyak menimbulkan kontroversi, khususnya di kalangan ilmuwan sosial. Suatu ungkapan yang hampir menjadi stereotip dalam percakapan sehari- hari menggambarkan seolah-olah agama merupakan hambatan terhadap proses modernisasi dan industrialisasi. Meskipun pada beberapa kasus mungkin asumsi itu benar, misalnya ada agama yang menentang program Keluarga Berencana (KB) padahal menurut para ahli mutlak diperlukan di negaranegara berkembang. Tetapi generalisasi bahwa agama merupakan rintangan modernisasi dan industrialisasi tidak dapat dibenarkan.

Pada dasarnya dalam kehidupan modern, kita sebagai manusia tidak bisa terlepas dari iman dan taqwa. Karena dengan kita beriman dan bertaqwa, kita dapat mencegah dan menyelamatkan diri dari hal-hal yang menyesatkan atau dari segala sesuatu yang tidak baik. Selain itu, kita juga dapat menentukan apakah modernisasi tersebut dianggap sebagai suatu kemajuan atau tidak, dipandang bermanfaat atau tidak, diperlukan atau sebaliknya perlu dihindari.

\section{Motivasi}

Motivasi adalah proses yang menjelaskan intensitas, arah, dan ketekunan seorang individu untuk mencapai tujuannya.Tiga elemen utama dalam definisi ini diantaranya adalah intensitas, arah, dan ketekunan.

Berdasarkan teori hierarki kebutuhan Abraham Maslow, teori X dan teori Y Douglas McGregor maupun teori motivasi kontemporer, arti motivasi adalah 'alasan' yang mendasari sebuah perbuatan yang dilakukan oleh seorang individu. Seseorang dikatakan memiliki motivasi tinggi dapat diartikan orang tersebut memiliki alasan yang sangat kuat untuk mencapai apa yang diinginkannya dengan mengerjakan pekerjaannya yang sekarang. Berbeda dengan motivasi dalam pengertian yang berkembang di masyarakat yang seringkali disamakan dengan 'semangat', seperti contoh dalam percakapan "saya ingin anak saya memiliki motivasi yang tinggi". Statemen ini bisa diartikan orang tua tersebut menginginkan anaknya memiliki semangat belajar yang tinggi. Maka, perlu dipahami bahwa ada perbedaan penggunaan istilah motivasi di masyarakat. Ada yang mengartikan motivasi sebagai sebuah alasan, dan ada juga yang mengartikan motivasi sama dengan semangat.

Dalam hubungan antara motivasi dan intensitas, intensitas terkait dengan seberapa giat seseorang berusaha, tetapi intensitas tinggi tidak menghasilkan prestasi kerja yang memuaskan kecuali upaya tersebut dikaitkan dengan arah yang menguntungkan organisasi. Sebaliknya elemen yang terakhir, ketekunan, merupakan ukuran mengenai berapa lama seseorang dapat mempertahankan usahanya.

Motivasi berasal dari bahasa Latin "movere", yang berarti menggerakkan. Menurut Weiner (1990) motivasi didefenisikan sebagai kondisi internal yang membangkitkan kita untuk bertindak, mendorong kita mencapai tujuan tertentu, dan membuat kita tetap tertarik dalam kegiatan tertentu. Menurut (Onny Siagian, 2020), motivasi dapat diartikan sebagai dorongan internal dan eksternal dalam diri seseorang yang diindikasikan dengan adanya; hasrat dan minat; dorongan dan kebutuhan; harapan dan cita-cita; penghargaan dan penghormatan. Sedangkan (Wijaya, 2017) menjelaskan bahwa motivasi berasal dari bahasa Inggris "motivation" yang berarti dorongn atau pengalasan untuk melakukan suatu aktifitas hingga mencapai tujuan.

Dari serangkaian pengertian para ahli diatas, maka dapat disimpulkan bahwa motivasi adalah sesuatu alasan yang mendorong seseorang untuk melakukan; menyelesaikan; menghentikan; dsb, suatu aktifitas guna mencapai tujuan tertentu yang diinginkan dari motivasi tersebut. 
Teori motivasi yang paling terkenal adalah hierarki teori hierarki kebutuhan milik Abraham Maslow. Ia membuat hipotesis bahwa dalam setiap diri manusia terdapat hierarki dari lima kebutuhan, yaitu fisiologis (rasa lapar, haus, seksual, dan kebutuhan fisik lainnya), rasa aman (rasa ingin dilindungi dari bahaya fisik dan emosional), sosial (rasa kasih sayang, kepemilikan, penerimaan, dan persahabatan), penghargaan (faktor penghargaan internal dan eksternal), dan aktualisasi diri (pertumbuhan, pencapaian potensi seseorang, dan pemenuhan diri sendiri).

Maslow memisahkan lima kebutuhan ke dalam urutan-urutan. Kebutuhan fisiologis dan rasa aman dideskripsikan sebagai kebutuhan tingkat bawah sedangkan kebutuhan sosial, penghargaan, dan aktualisasi diri sebagai kebutuhan tingkat atas. Perbedaan antara kedua tingkat tersebut adalah dasar pemikiran bahwa kebutuhan tingkat atas dipenuhi secara internal sementara kebutuhan tingkat rendah secara dominan dipenuhi secara eksternal.

Teori kebutuhan Maslow telah menerima pengakuan luas di antara manajer pelaksana karena teori ini logis secara intuitif. Namun, penelitian tidak memperkuat teori ini dan Maslow tidak memberikan bukti empiris dan beberapa penelitian yang berusaha mengesahkan teori ini tidak menemukan pendukung yang kuat.

\section{Kewirausahaan}

Kewirausahaan (bahasa Inggris: Entrepreneurship) atau Wirausaha adalah proses mengidentifikasi, mengembangkan, dan membawa visi ke dalam kehidupan. Visi tersebut bisa berupa ide inovatif, peluang, cara yang lebih baik dalam menjalankan sesuatu. Hasil akhir dari proses tersebut adalah penciptaan usaha baru yang dibentuk pada kondisi risiko atau ketidakpastian.

Kewirausahaan memiliki arti yang berbeda-beda antar para ahli atau sumber acuan karena berbeda-beda titik berat dan penekanannya. (Hilyati Milla, 2010) misalnya, mendefinisikan kewirausahaan sebagai bekerja sendiri (self- employment). Seorang wirausahawan membeli barang saat ini pada harga tertentu dan menjualnya pada masa yang akan datang dengan harga tidak menentu. Jadi definisi ini lebih menekankan pada bagaimana seseorang menghadapi risiko atau ketidakpastian.

Berbeda dengan para ahli lainnya, menurut (Nursito \& Nugroho, 2013), kegiatan kewirausahaan mencakup indentfikasi peluang-peluang di dalam sistem ekonomi sedangkan menurut (Aprijon, 2013) kewirausahaan mencakup kegiatan yang dibutuhkan untuk menciptakan atau melaksanakan perusahaan pada saat semua pasar belum terbentuk atau belum teridentifikasi dengan jelas, atau komponen fungsi produksinya belum diketahui sepenuhnya dan menurut Peter Drucker, kewirausahaan adalah kemampuan untuk menciptakan sesuatu yang baru dan berbeda. Orang yang melakukan kegiatan kewirausahaan disebut wirausahawan. Muncul pertanyaan mengapa seorang wirausahawan (entrepreneur) mempunyai cara berpikir yang berbeda dari manusia pada umumnya. Mereka mempunyai motivasi, panggilan jiwa, persepsi dan emosi yang sangat terkait dengan nilai nilai, sikap dan perilaku sebagai manusia unggul.

Kewirausahaan berasal dari kata wira dan usaha.Wira berarti pejuang, pahlawan, manusia unggul, teladan, berbudi luhur, gagah berani dan berwatak agung. Usaha adalah perbuatan amal, bekerja, dan berbuat sesuatu. Jadi wirausaha adalah pejuang atau pahlawan yang berbuat sesuatu.

Wirausaha secara historis sudah dikenal sejak diperkenalkan oleh Richard Castillon pada tahun 1755. Di luar negeri, istilah kewirausahaan telah dikenal sejak abad 16, sedangkan di Indonesia baru dikenal pada akhir abad 20. Beberapa istilah wirausaha seperti di Belanda dikenal dengan ondernemer, di Jerman dikenal dengan unternehmer. Pendidikan kewirausahaan mulai dirintis sejak 1950-an di beberapa negara seperti Eropa, Amerika, dan Kanada. Bahkan sejak 1970-an banyak universitas yang mengajarkan kewirausahaan atau manajemen usaha kecil. Pada tahun 1980-an, hampir 500 sekolah di Amerika Serikat memberikan pendidikan kewirausahaan. DI Indonesia, kewirausahaan dipelajari baru terbatas pada beberapa sekolah atau perguruan tinggi tertentu saja. Sejalan dengan perkembangan dan tantangan seperti adanya krisis ekonomi, 
pemahaman kewirausahaan baik melalui pendidikan formal maupun pelatihan-pelatihan di segala lapisan masyarakat kewirausahaan menjadi berkembang.

Menurut (Abajobir et al., 2017), yang dikutip oleh Bygrave, proses kewirausahaan diawali dengan adanya inovasi. Inovasi tersebut dipengeruhi oleh berbagai faktor baik yang berasal dari pribadi maupun di luar pribadi, seperti pendidikan, sosiologi, organisasi, kebudayaan dan lingkungan. Faktor-faktor tersebut membentuk 'locus of control', kreativitas, keinovasian, Implementasi, dan pertumbuhan yang kemudian berkembangan menjadi wirausahawan yang besar. Secara internal, keinovasian dipengaruhi oleh faktor yang berasal dari individu, seperti locus of control, toleransi, nilai-nilai, pendidikan, pengalaman. Sedangkan faktor yang berasal dari lingkungan yang memengaruhi diantaranya model peran, aktivitas, dan peluang. Oleh karena itu, inovasi berkembang menjadi kewirausahaan melalui proses yang dipengaruhi lingkungan, organisasi, dan keluarga.

\section{PENUTUP}

Pelaksanaan kegiatan pengabdian kepada masyarakat oleh lembaga penelitian dan pengembangan masyarakat (LPPM) Universitas Bina Sarana Informatika yang dilakukan oleh dosendosen program studi Manajemen bertempat di Aula Kantor Desa Gunung Picung, dihadiri oleh RT, RW, TP PKK Desa, Kader Posyandu, Tokoh Masyarakat dan Tokoh Agama dan telah berjalan dengan lancar serta mendapat sambutan hangat dari tempat pelaksanaan kegiatan ini yaitu Desa Gunung Picung, Kecamatan Pamijahan, Kota Bogor, Jawa Barat.

Harapan kami dengan pengabdian ini dapat membuka wawasan dari masyarakat yang kami berikan pembelajaran dan praktek dalam bidang manajemen khususnya kewirausahan dan keagamaan sekaligus bahan kajian dan masukan bagi masyarakat tersebut untuk dapat menerapkannya dalam kehidupan sehari-hari, sehingga dapat membantu dan meningkatkan tingkat kehidupan dan kesejahteraan mereka pada masa yang akan datang.

\section{DAFTAR PUSTAKA}

Putra, R. S. 2013. Pengaruh Budaya Perusahaan Terhadap Prestasi Kerja Karyawan PT Pembangkitan Jawa-Bali Surabaya Unit Pelayanan Pemeliharaan. Journal Vol.15 No.2 (131-140)

Abajobir, A. A., Abate, K. H., Abbafati, C., Abbas, K. M., Abd-Allah, F., Abdulkader, R. S., Abdulle, A. M., Abebo, T. A., Abera, S. F., Aboyans, V., Abu-Raddad, L. J., Ackerman, I. N., Adedeji, I. A., Adetokunboh, O., Afshin, A., Aggarwal, R., Agrawal, S., Agrawal, A., Ahmed, M. B., ... Zuhlke, L. J. (2017). Global, regional, and national disability-adjusted life-years (DALYs) for 333 diseases and injuries and healthy life expectancy (HALE) for 195 countries and territories, 1990-2016. In The Lancet.

Ade Onny Siagian, N. R. (2020). PELATIHAN PEMBUATAN BUKU BESAR DAN NERACA SALDO UNTUK PERUSAHAAN JASA DI PPQ NAHWA NUR BOGOR. Aksara Public, 4(4), 179-188.

Aprijon, A. (2013). Kewirausahaan dan Pandangan Islam. Menara Riau.

Cahyono, Y., Jihadi, M., Arifin, Z., \& Purnamasari, W. (2020). Do Servant Leadership Influence Market Performance? Evidence from Indonesian Pharmacy Industries. Systematic Reviews in Pharmacy, 11(9), 439-451.

Hilyati Milla. (2010). Pendidikan Kewirausahaan : Hilyati, Pendidikan Kewirausahaan.

Mujib, A. (2017). Syari’ Ah Fraud Model : Sebuah Konsep Dasar. Snaper-Ebis 2017.

Nursito, S., \& Nugroho, A. J. S. (2013). Analisis Pengaruh Interaksi Pengetahuan Kewirausahaan dan Efikasi Diri Terhadap Intensi Wirausaha. Kiat Bisnis. 
O. Siagian, A. (2020). Analisis Jaringan Antara Pengembangan Produk dan Kualitas Pelayanan dengan Kepuasan Pelanggan PT. Adhi Karya. Journal Economy and Currency Study (JECS), 2(2), 34-43.

Onny Siagian, A. (2020). CHARACTER BUILDING RELASI DALAM KEHIDUPAN BERAGAMA DAN BERSOSIAL (V. Meilinda \& A. S. Wijaya (eds.)). Syntax Computama.

Saepudin, D. M., Solahudin, M., \& Khairani, I. F. S. R. (2007). IMAN DAN AMAL SALEH DALAM ALQURAN (STUDI KAJIAN SEMANTIK). Al-Bayan: Jurnal Studi Ilmu AlQur'an Dan Tafsir. https://doi.org/10.15575/al-bayan.v2i1.1805

Siagian, A. O., Martiwi, R., \& Indra, N. (2020). Kemajuan Pemasaran Produk Dalam Memanfaatkan Media Sosial Di Era Digital. Jurnal Pemasaran Kompetitif. https://doi.org/10.32493/jpkpk.v3i3.4497

Siagian, A.O., N Indra. (2019). Pengetahuan Akuntansi Pelaku Usaha Mikro Kecil dan Menengah (UMKM) Terhadap Laporan Keuangan. Syntax Literate; Jurnal Ilmiah Indonesia 4 (12), 17 35 .

Siagian, A.O. (2020) ANALYSIS OF THE EFFECT OF OCCUPATIONAL SAFETY AND HEALTH ON EMPLOYEE PERFORMANCE OF PT. WIJAYA KARYA (PERSERO) TBK. AT THE NAYUMI SAM TOWER MALANG PROJECT International Journal of Business and Information Technology 1 (1).

Siagian, A.O. (2021). Pelatihan Pengelolaan Keuangan Keluarga di Masa Pandemi Covid-19 Bagi Ibu Ibu PKK RW.06 Kelurahan Gembor Kota Tangerang, Universitas Bina Sarana Informatika, Jakarta, Indonesia, DOI: https://doi.org/10.37729/abdimas.vi.872

Soedarwo, V. S. D., Zuriah, N., Yuliati, R., \& Suwignyo. (2017). Pemberdayaan masyarakat melalui pendidikan nonformal berbasis potensi lokal dalam membangun desa wisata adat. Jurnal Sosiologi Pendidikan Humanis.

Sonya, E. R., \& Wulan, E. R. (2018). Pemberdayaan Organisasi Sosial Kepemudaan Karang Taruna Bina Swakarsa Kecamatan Solokan Jeruk Melalui Program Keagamaan. Al-Khidmat. https://doi.org/10.15575/jak.v1i1.3324

Wijaya, D. (2017). Pengaruh Motivasi dan Gaya Hidup Terhadap Keputusan Pembelian. Perspektif.

Wijoyo, H. (2020). Socialization Of The Accreditation Asessment System (SISPENA) Of The National Accreditation Board For Early Childhood Education (PAUD) And Non Formal Education (PNF) In Bengkalis, Riau Province. Jurnal Humanities Pengabdian Kepada Masyarakat, 1(1), 103-111.

Wijoyo, H. (2020). Socialization Of The Accreditation Asessment System (SISPENA) Of The National Accreditation Board For Early Childhood Education (PAUD) And Non Formal Education (PNF) In Bengkalis, Riau Province. Jurnal Humanities Pengabdian Kepada Masyarakat, 1(1), 103-111.

Wijoyo, H. (2020). Sosialiasi Sistem Penilaian Akreditasi (SisPenA) Badan Akreditasi Nasional Pendidikan Anak Usia Dini (PAUD) dan Pendidikan Non Formal (PNF) di Kecamatan Bantan, Kabupaten Bengkalis, Propinsi Riau. ARBITRASE: Journal of Economics and Accounting, 1(1), 7-10.

Wijoyo, H., \& Haudi, H. (2021, January). PENYULUHAN TEKNIK PEMASARAN KERUPUK RASA JENGKOL "DONG DONG SNACK" PEKANBARU. In PROSIDING SENANTIAS: Seminar Nasional Hasil Penelitian dan Pengabdian kepada Masyarakat (Vol. 1, No. 1, pp. 643-650). 


\section{DOKUMENTASI FOTO KEGIATAN}

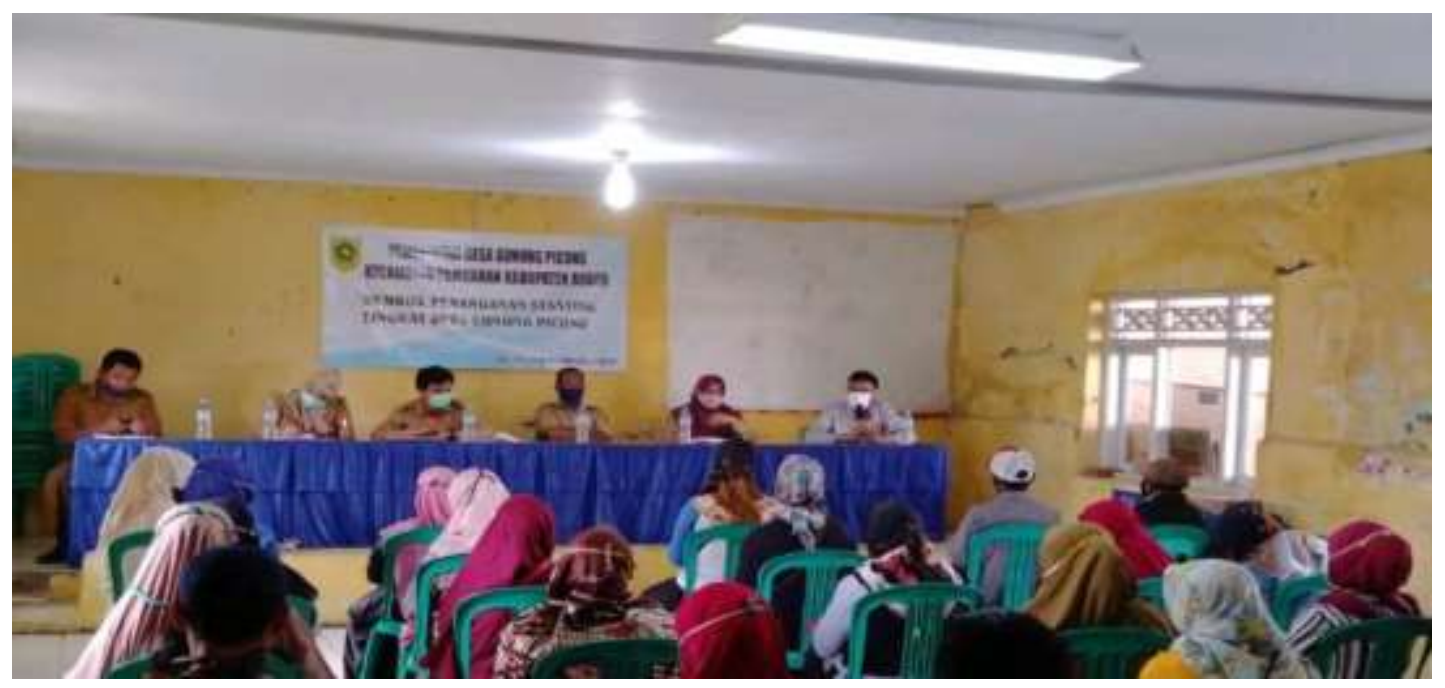

\section{Gambar 2}

(Aula Kantor Desa Gunung Picung, dihadiri oleh, RT, RW, TP PKK Desa, Kader Posyandu, Tokoh Masyarakat dan Tokoh Agama)

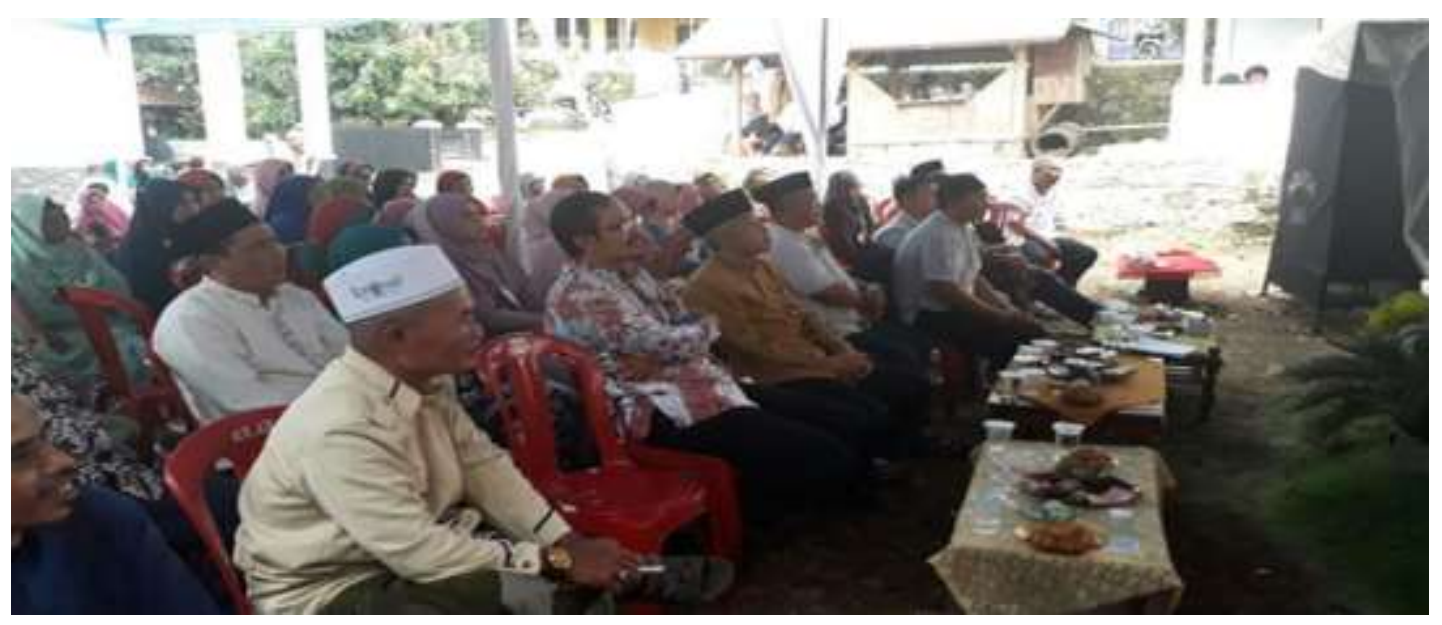

\section{Gambar 3}

(Peserta penuh semangat mendengarkan ceramah keagamaan dan materi ilmu, pemahaman keagamaan dan keterampilan kewirausahaan) 